\title{
Relationship between Precipitation and Annual Rangeland Herbage Production in Southeastern Kansas
}

\author{
THOMAS N. SHIFLET AND HARLAND E. DIETZ
}

Highlight: Herbage production on the loamy upland range site in southeastern Kansas is related to seasonal precipitation. April through September precipitation gave the most reliable predictor of total herbage production. However, this value cannot be determined early enough in the season to make adjustments in livestock numbers on seasonally grazed ranges. May through July precipitation, though less precise than that for April through September, can also be used to predict herbage yields and is timely enough for seasonal adjustments in livestock.

Big bluestem was the only major species that showed significant correlation with seasonal precipitation. May through July precipitation was the best predictor of the herbage produced by this species.

The rangeland operator is constantly confronted with the problem of adjusting livestock numbers to available forage. Numerous attempts have been made to correlate herbage production with various climatic phenomena in order to make timely adjustments in livestock numbers for economic livestock production and conservation of the rangeland resource. Several studies have been conducted in the Great Plains region to correlate herbage yield with various seasons or periods of precipitation.

Hulett and Tomanek (1969) working in west-central Kansas reported the measurement of monthly herbage production from 1941 through 1964. Correlation of precipitation with total yield of herbage was analyzed. Seasonal moisture recorded during the growing season, April through September, gave the highest correlation $(r=.626)$. Of the early season moisture measured, the May-June precipitation gave the best correlation $(r=.516)$. Some relationships were established for production of various groups of plants. For shortgrasses, seasonal moisture gave $r=.601$ while an even better correlation of $r=.612$ was found for July rainfall. The correlations computed were significant, and it was concluded that total herbage production could be predicted on the basis of May-June rainfall using simple linear regression techniques.

Considerably higher correlations were found in North Dakota by Rogler and Haas (1947). A highly significant $r=.76$ was found between total herbage production and April through July precipitation. When soil moisture in the surface 6 feet of the soil was included in the computations, the correlation coefficient was increased to 84 . Correlation of livestock gains with precipitation and precipitation plus soil moisture followed a similar pattern.

Sandhills rangeland in excellent condition was studied for 7 years by Dahl (1963) in eastern Colorado. May 1 through

Authors are regional range conservationist, Soil Conservation Service, U.S. Department of Agriculture, Lincoln, Nebraska, and state range conservationist, Soil Conserv. Serv., U.S. Dep. Agr., Salina, Kansas.

Manuscript received July 25, 1973.
October 1 precipitation was highly correlated with total growing season production $(r=.893)$. Precipitation received during the previous two years was significantly correlated with total production $(r=.830)$. Highest correlations computed occurred between production from May to June 20 and precipitation received the previous 2 years plus evapotranspiration water, which gave a correlation coefficient of .983 . Evapotranspiration water was defined as the soil moisture available at the beginning of the season plus precipitation received, less the soil moisture remaining at the end of the study period.

Rauzi (1964), working with shortgrass vegetation in Wyoming, found May-June precipitation over a 5-year period to have a highly significant correlation $(r=.675)$ with total yield of perennial vegetation. April through August precipitation was even more highly correlated $(r=.745)$. May-June moisture accounted for $46 \%$ of the variation in perennial vegetation production, while $65 \%$ was accounted for by precipitation received during the April-August period. Smoliak (1956) determined that shortgrass rangeland production in Canada was highly correlated with May-June precipitation, computing a correlation coefficient of .859 . He was able to predict forage production and grazing capacity as early as July 1 by using regression analysis.

No studies of this nature have been reported from the tallgrass prairies of the Great Plains. However, Hazell (1965) studied an Oklahoma prairie on Parsons silt loam soil for 2 years and found that production declined from $2152 \mathrm{lb} / \mathrm{acre}$ the first year to $1824 \mathrm{lb} /$ acre the second. The decline in yield was apparently related to considerably less precipitation in May of the second year than was received the first year of the study.

The study reported here was undertaken to determine if meaningful correlations existed between herbage production and various increments of precipitation in southeastern Kansas and to ascertain if production could be predicted as an aid to proper range management.

\section{Methods and Procedures}

Data for this study were collected over eight years from excellent range condition stands on specific soil taxonomic units (series and phase) comprising the loamy upland range site in the 35 to 40 -inch precipitation zone in southeastern Kansas. Estimates of air-dry herbage production were made from October 1 to October 15 annually, using the double sampling technique described by Hilmon (1959) and Blair (1959). Each observation consisted of 10 subplots. Subplots were rectangular in shape and ecompassed $1.92 \mathrm{ft}^{2}$ as described by Shoop and McIllvain (1963). Precipitation values were obtained from the recording station closest to where each herbage estimate was made.

Statistical procedures for the study followed the methods outlined by Snedecor and Cochran (1967). 


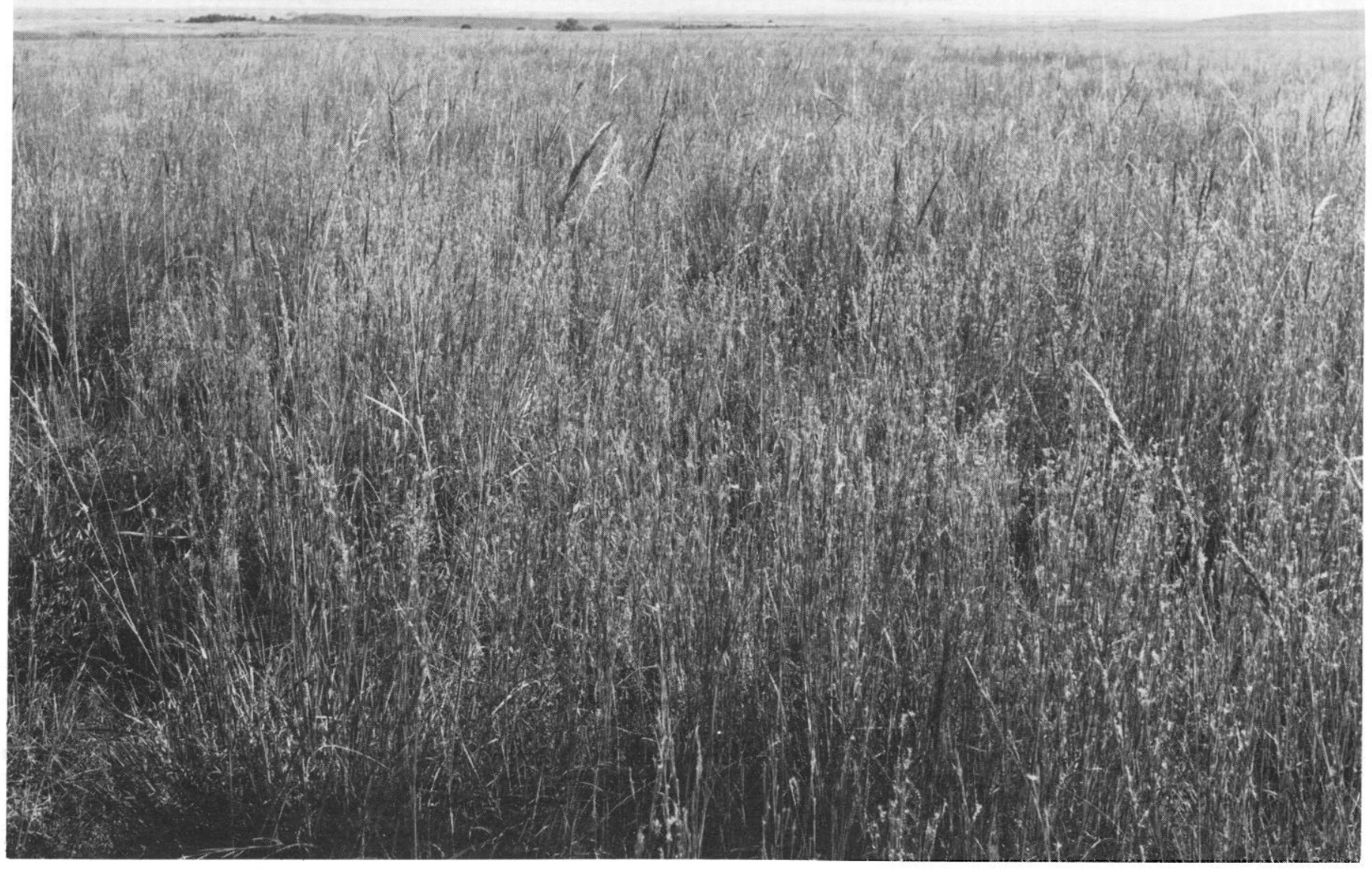

Fig. 1. Landscape view of the loamy upland range site in southeastern Kansas.

These data were collected initially for the purpose of preparing and refining range site descriptions (Renner and Allred, 1962). Later all quality data on hand were transferred to a standard format for use in an automated storage and retrieval system being developed by the Soil Conservation Service as described by Shiflet (1970). This system does not currently call for recording monthly precipitation with production and composition values since reliable sources of this information are not generally available. However, a block of data was available that included reliable monthly rainfall recorded at nearby recording stations. These data included production determinations from three soil taxonomic units: Dennis silt loam, Lulu silt loam, and Bates loam, all major components of the Loamy Upland range site in southeastern Kansas. ${ }^{1}$ Six sets of data from each soil could be blocked by years and analyzed for differences in production and species composition between the three soils. Analysis of variance revealed that no significant differences in total production or in the production of little bluestem (Andropogon scoparius), big bluestem (A. gerardi), Indiangrass (Sorghastrum nutans), or switchgrass (Panicum virgatum) existed. Based on this analysis, all the available data from these three soils that reflected a range condition rating of $85 \%$ of climax composition or higher and which included monthly rainfall values were pooled. In all, 25 observations were available (Table 1). The pooled data were subjected to linear regression and correlation analysis to determine the relationship of amounts of precipitation to total herbage production and to the production of each of the four

${ }^{1}$ Range Site Descriptions and Technicians Guide to Range Condition, Soil Conservation Service, U.S. Dep. Agr. major species-little bluestem, big bluestem, Indiangrass, and switchgrass-and to see if herbage production could be predicted from precipitation.

Five seasons of precipitation were selected. Since production determinations were made from October 1 through 15 , the precipitation from January through September was selected for study rather than the yearly total. Other seasons included pre-season (January through April); growing season (April through September), May and June, and May through July.

\section{Results}

Correlation coefficients between the various periods of precipitation and total and species production are shown in Table 2. All correlations between total production and seasons of precipitation were significant at the $5 \%$ probability level except for the January through April period. Big bluestem was the only species analyzed that showed significant correlations. It was significantly correlated with all seasons except January-April.

Total herbage production was most highly correlated with April-September precipitation. This resulted in a higher correlation coefficient (.784) than that found by Hulett and Tomanek (1969) in western Kansas. They reported total production and April-September precipitation to yield a correlation of .626. Big bluestem production correlated most highly with May-July precipitation $(r=.755)$.

Linear regression analysis showed significant regression coefficients for all seasons of precipitation on total production 
Table 1. Precipitation (inches) for selected periods and herbage estimates (lb/acre) for total production and for the production of four major species for the Loamy Upland site in southeastern Kansas. ${ }^{1}$

\begin{tabular}{|c|c|c|c|c|c|c|c|c|c|c|}
\hline \multirow[b]{2}{*}{$\begin{array}{c}\text { Data } \\
\text { set no. }\end{array}$} & \multicolumn{5}{|c|}{ Precipitation } & \multicolumn{5}{|c|}{ Herbage production $^{2}$} \\
\hline & $\begin{array}{l}\text { Jan.- } \\
\text { Sept. }\end{array}$ & $\begin{array}{l}\text { Jan.- } \\
\text { Apr. }\end{array}$ & $\begin{array}{l}\text { Apr.- } \\
\text { Sept. }\end{array}$ & $\begin{array}{l}\text { May- } \\
\text { June }\end{array}$ & $\begin{array}{l}\text { May- } \\
\text { July }\end{array}$ & $\begin{array}{l}\text { Total } \\
\text { prod. }\end{array}$ & ANSC2 & ANGE & SONU2 & PAVI2 \\
\hline 1 & 21.5 & 5.0 & 18.2 & 9.0 & 11.1 & 4646 & 1980 & 976 & 782 & 0 \\
\hline 2 & 21.5 & 5.0 & 18.2 & 9.0 & 11.1 & 5258 & 2284 & 1098 & 486 & 318 \\
\hline 3 & 22.8 & 5.4 & 20.5 & 8.7 & 8.9 & 4854 & 2224 & 1748 & 264 & 0 \\
\hline 4 & 24.5 & 6.6 & 21.6 & 7.8 & 8.0 & 5289 & 1503 & 636 & 2256 & 0 \\
\hline 5 & 28.6 & 3.9 & 24.7 & 6.6 & 11.8 & 5612 & 3348 & 940 & 525 & 205 \\
\hline 6 & 21.5 & 5.0 & 18.2 & 9.0 & 11.1 & 4660 & 2070 & 1398 & 220 & 400 \\
\hline 7 & 18.8 & 5.6 & 15.6 & 3.7 & 8.2 & 3028 & 1442 & 308 & 558 & 0 \\
\hline 8 & 18.8 & 5.6 & 15.6 & 3.7 & 8.2 & 4270 & 2296 & 486 & 586 & 76 \\
\hline 9 & 28.6 & 3.9 & 24.7 & 6.6 & 11.8 & 6187 & 4426 & 68 & 402 & 112 \\
\hline 10 & 43.4 & 9.1 & 38.2 & 16.8 & 21.1 & 6071 & 1320 & 3058 & 133 & 247 \\
\hline 11 & 18.8 & 5.6 & 15.6 & 3.7 & 8.2 & 5458 & 3488 & 532 & 926 & 64 \\
\hline 12 & 21.5 & 5.0 & 18.2 & 9.0 & 11.1 & 5236 & 1062 & 2295 & 558 & 791 \\
\hline 13 & 21.5 & 5.0 & 18.2 & 9.0 & 11.1 & 5776 & 1982 & 1616 & 110 & 824 \\
\hline 14 & 24.5 & 6.6 & 21.6 & 7.8 & 8.0 & 5815 & 580 & 4541 & 0 & 75 \\
\hline 15 & 30.6 & 13.1 & 21.7 & 7.1 & 11.2 & 5640 & 2798 & 1356 & 615 & 306 \\
\hline 16 & 37.7 & 8.3 & 32.8 & 12.9 & 17.8 & 6438 & 2840 & 1680 & 765 & 0 \\
\hline 17 & 19.5 & 3.9 & 16.3 & 3.9 & 4.8 & 4060 & 2775 & 42 & 528 & 280 \\
\hline 18 & 20.5 & 6.0 & 16.0 & 7.0 & 9.9 & 3337 & 2498 & 5 & 0 & 77 \\
\hline 19 & 33.3 & 6.5 & 30.4 & 9.2 & 19.2 & 6593 & 437 & 5432 & 0 & 416 \\
\hline 20 & 20.5 & 6.0 & 16.0 & 7.0 & 10.0 & 3600 & 2120 & 5 & 0 & 45 \\
\hline 21 & 37.8 & 8.3 & 32.8 & 12.9 & 17.8 & 6438 & 2840 & 1680 & 864 & 0 \\
\hline 22 & 31.7 & 6.5 & 30.4 & 9.2 & 19.2 & 6533 & 457 & 5427 & 0 & 396 \\
\hline 23 & 19.7 & 4.1 & 19.7 & 3.9 & 4.8 & 4060 & 2675 & 32 & 628 & 260 \\
\hline 24 & 18.6 & 5.0 & 15.0 & 7.0 & 10.0 & 3373 & 2598 & 15 & 0 & 87 \\
\hline 25 & 18.5 & 5.0 & 15.0 & 7.0 & 10.0 & 3600 & 2120 & 5 & 0 & 55 \\
\hline
\end{tabular}

\footnotetext{
${ }^{1}$ Production values based on an average of 10 subplots.
}

${ }^{2}$ Symbols for species conform to National List of Scientific Plant Names, Soil Conservation Service $(1971):$ ANSC2 $=$ little bluestem, ANGE = big bluestem, SONU2 = Indiangrass, and PAVI2 = switchgrass.

except for pre-season (January-April) moisture. Total-to-date (January-September) and growing season (April-September) precipitation were highly correlated with total herbage production (Table 2), with April-September exhibiting a slightly closer relationship ( $r=.784$ compared to $r=.766$ ).

Coefficient of determination $\left(r^{2}\right)$ computations revealed that $58.7 \%$ of the variation in total herbage production could be accounted for by the variation in January-September precipitation, while a slightly higher value, $r^{2}=61.5$, was obtained for the April-September season. May-June and May-July precipitation accounted for 33.1 and $45.5 \%$ of the variation in total production, respectively.

Both January-September and April-September precipitation can be used to estimate total production (Figs. 2 and 3) with April-September (Fig. 3) giving the better prediction equation. Variability of the data resulted in relatively high deviations from regression causing somewhat wide confidence intervals as shown in both Figures 2 and 3 . This fact would make predications of total production from high or low precipitation values that occur at the extreme range of these data highly unreliable.

Prediction of total production from May-June and MayJuly precipitation are less reliable than for either JanuarySeptember or April-September due to wider confidence intervals as shown in Figures 4 and 5.

Production of big bluestem was significantly correlated with all seasons of precipitation except pre-season (JanuaryApril) as shown in Table 2. Highest correlation was with May-July moisture where $r=.755$. This points up the fact that the amount of herbage contributed by big bluestem on this site is not only dependent on the amount of precipitation but also on the season in which it occurs, a phenomenon previously observed in field operations.

Figure 6 shows the relationship between big bluestem
Table 2. Simple correlation coefficients between seasonal precipitation and total herbage production and the production of four major species on the Loamy Upland range site in southeastern Kansas.

\begin{tabular}{llccrr}
\hline & \multicolumn{5}{c}{ Species } \\
\cline { 2 - 6 } $\begin{array}{c}\text { Precipitation } \\
\text { season }\end{array}$ & Total & $\begin{array}{c}\text { Little } \\
\text { bluestem }\end{array}$ & $\begin{array}{c}\text { Big } \\
\text { bluestem }\end{array}$ & $\begin{array}{c}\text { Indian- } \\
\text { grass }\end{array}$ & \multicolumn{1}{c}{$\begin{array}{c}\text { Switch- } \\
\text { grass }\end{array}$} \\
\hline Jan.-Sept. & $0.766^{*}$ & -0.148 & $0.604^{*}$ & 0.081 & 0.000 \\
Jan.-Apr. & 0.380 & -0.038 & 0.316 & 0.029 & -0.048 \\
Apr.-Sept. & $0.784^{*}$ & -0.199 & $0.669^{*}$ & 0.063 & 0.036 \\
May-June & $0.575^{*}$ & -0.268 & $0.528^{*}$ & -0.077 & 0.164 \\
May-July & $0.675^{*}$ & -0.300 & $0.755^{*}$ & -0.115 & 0.095 \\
\hline
\end{tabular}

*Significant at the $5 \%$ probability level.

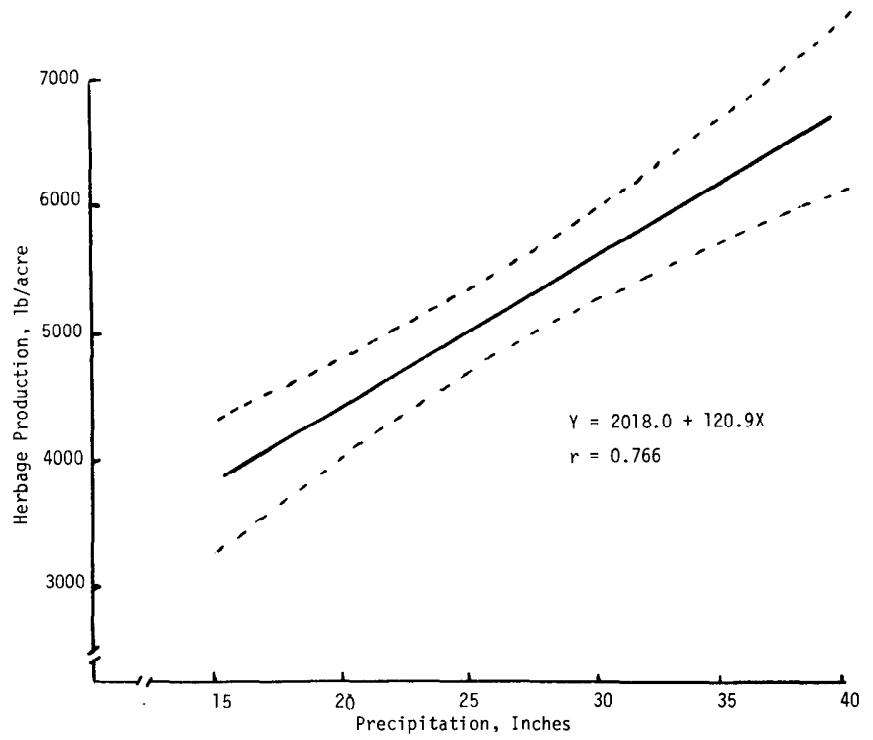

Fig. 2. Relationship between total herbage production and Januarythrough-September precipitation in southeastern Kansas. Dashed lines indicate $5 \%$ confidence intervals. 


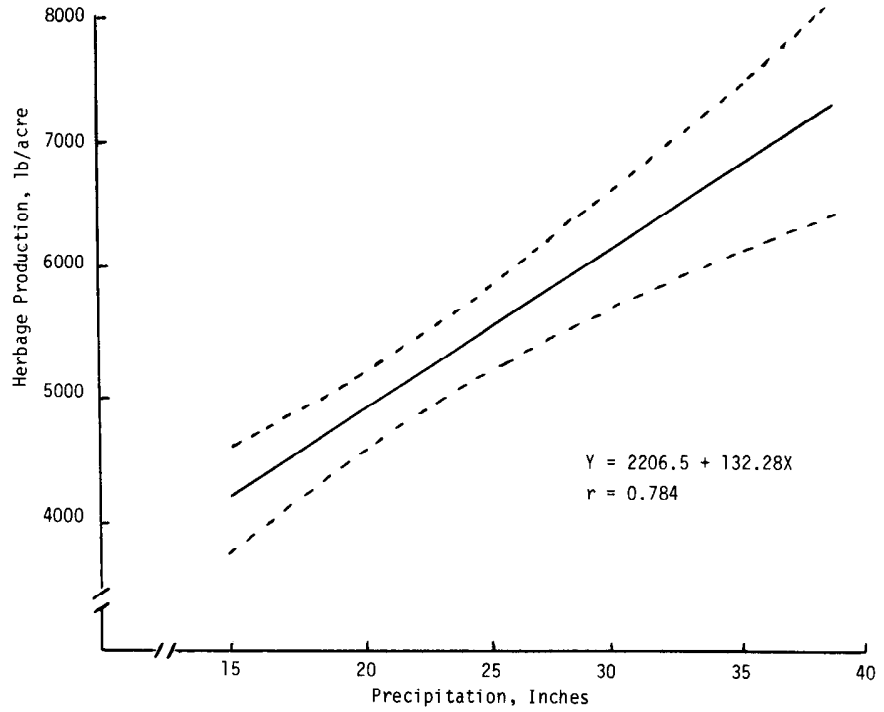

Fig. 3. Relationship between total herbage production and Aprilthrough-September precipitation in southeastern Kansas. Dashed lines indicate $5 \%$ confidence intervals.

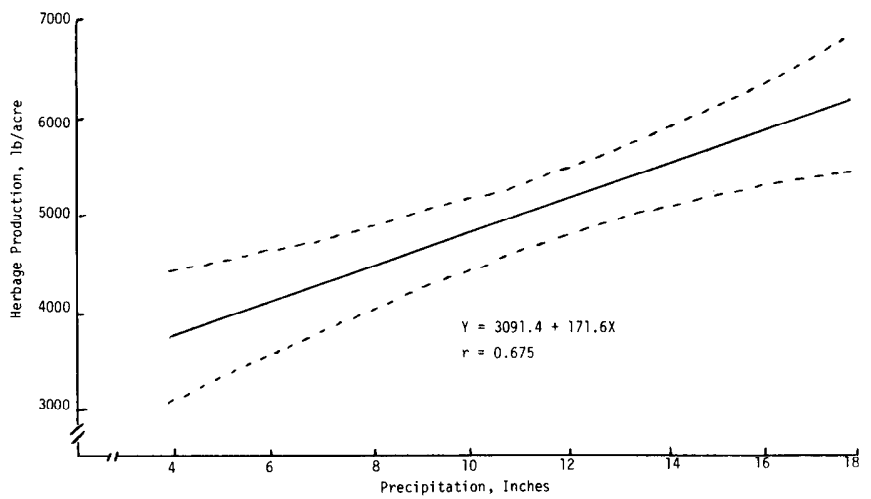

Fig. 5. Relationship between total herbage production and Maythrough July precipitation in southeastern Kansas. Dashed lines indicate 5\% confidence intervals.

production and May-July precipitation, the season showing the highest correlation. Variability of the production values resulted in relatively wide confidence intervals as is shown in Figure 6. This equation can be used for "rough" estimates of big bluestem production on the Loamy Upland range site.

\section{Conclusions}

Total production from the Loamy Upland range site can be predicted with a fair degree of confidence from either January-September or April-September precipitation. However, both are limited in their management application since no estimates can be made until October 1 , which is generally too late in the season to make meaningful adjustments in livestock numbers if ranges are grazed during the growing season. However, such predictions could be used to estimate total production to fill missing data for analytical purposes or to estimate available forage for fall and winter grazing if ranges are ungrazed during the growing season.

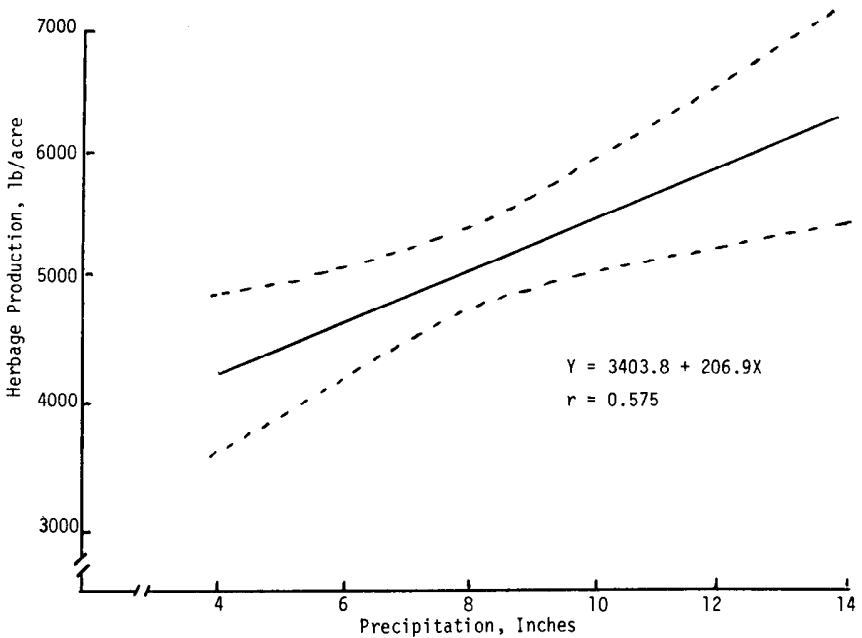

Fig. 4. Relationship between total herbage production and Maythrough-June precipitation in southeastern Kansas. Dashed lines indicate $5 \%$ confidence intervals.

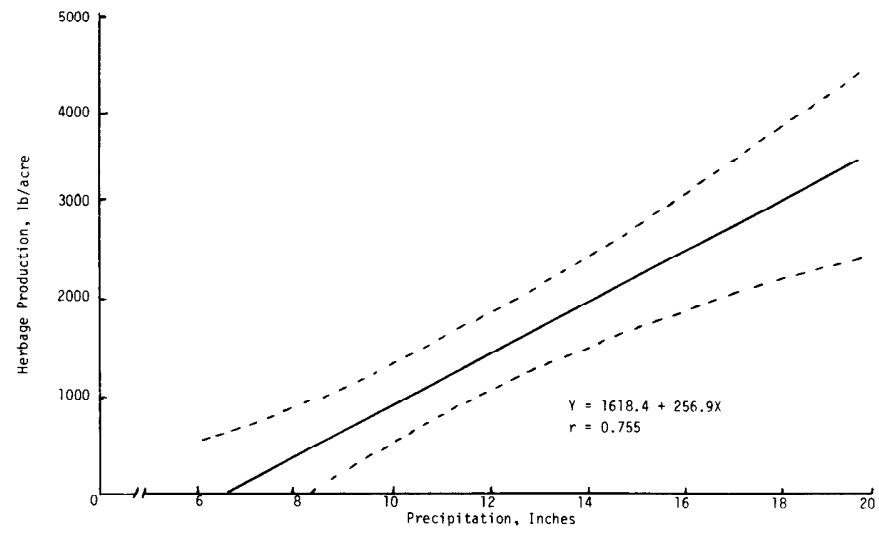

Fig. 6. Relationship between big bluestem production and May. through-July precipitation in southeastern Kansas. Dashed lines indicate $5 \%$ confidence intervals.

May-July precipitation yielded a somewhat less precise estimate of herbage production than either January-September or April-September values. However, predictions based on this period have better management applications than the others. Estimates of seasonal herbage production made by August could be used to adjust livestock numbers several weeks before the end of the usual grazing season.

Except for big bluestem, no prediction of individual species could be made from the increments of precipitation studied. May-July precipitation can be used to predict big bluestem production prior to the end of the growing season. Such a prediction would be primarily of academic interest. However, it would give some indication of the quality of forage available to livestock and the partial composition of the hay if harvested after August 1.

It is anticipated that as more refined data are assembled, correlations can be determined for additional important species, thus improving the reliability of predictions for total herbage production. 


\section{Literature Cited}

Blair, Robert M. 1959. Weight technique for sampling browse production on deer ranges. In Techniques and Methods of Measuring Understory vegetation. Southern and Southeastern Forest Exp. Stations, Forest Serv. U. S. Dep. Agr. p. 26-31.

Dahl, B. E. 1963. Soil moisture as a predictive index to forage yield for the sandhills range type. J. Range Manage. 16:128-132.

Hazell, Don B. 1965. The claypan range site in northern Osage County, Oklahoma. J. Range Manage. 18:94-96.

Hilmon, J. B. 1959. Determination of herbage weight by doublesampling: Weight estimate and actual weights. In Techniques and Methods of Measuring Understory Vegetation. Southern and Southeastern Forest Exp. Stations, U. S. Dep. Agr. p. 20-25.

Hulett, G. K., and G. W. Tomanek. 1969. Forage production on a clay upland site in western Kansas. J. Range Manage. 22:270-276.

Rauzi, Frank. 1964. Late-spring herbage production on shortgrass rangeland. J. Range Manage. 17:210-212.
Renner, F. G., and B. W. Allred. 1962. Classifying rangelands for conservation planning. U. S. Dep. Agr., Agr. Handbook 235. 48 p.

Rogler, George A., and Howard J. Haas. 1947. Range production as related to soil moisture and precipitation on the Northern Great Plains. J. Amer. Soc. Agron. 39:378-389.

Shiflet, Thomas N. 1970. Data acquisition, storage, and retrieval for range ecosystem planning. In Modelling and Systems Analysis in Range Science (Donald A. Jameson, ed.). Colo. State Univ., Range Sci. Dep. Sci. Series 5. p. 101-110.

Shoop, M. C., and E. H. McIllvain. 1963. The micro-unit forage inventory method. J. Range Manage. 16:172-179.

Smoliak, S. 1956. Influence of climatic conditions on forage production of shortgrass rangeland. J. Range Managc. 9:89-91.

Snedecor, George W., and William G. Cochran. 1967. Statistical methods (6th ed). Iowa State Univ. Press. Ames, Iowa. 593 p.

Soil Conservation Service. 1971. National list of scientific plant names. U. S. Dep. Agr. Soil Conserv. Serv. Lincoln, Nebr. 281 p. (Litho). 